Educational Guidance and Counseling Development Jounal p-ISSN:2615-3661 | e-ISSN: 2615-8358

Vol. 1, No. 1, April 2018, $32-51$

\title{
PENGARUH KONSEP DIRI DAN LOCUS OF CONTROL TERHADAP MOTIVASI BERPRESTASI
}

\author{
Eko Sujadi', Muhd. Odha Meditamar ${ }^{2}$, Bukhari Ahmad ${ }^{3}$, Anita Rahayu ${ }^{4}$ \\ 1,2,3,4, Institut Agama Islam Negeri (IAIN) Kerinci \\ email: ekosujadi@konselor.org
}

\begin{abstract}
Achievement motivation needs to be possessed by every individual. The aims of this research are to find out the effect of self concept and locus of control onachievement motivation in Islamic Guidance and Counseling Students of IAIN Kerinci. This research was descriptive \& correlation research by using quantitative approach. Data were collected by using the Tennessee Self Concept Scale by William H. Fitts modified by Julia Raymod Lorenz, Rotters Internal-External Locus of Control Scale (I-E Scale), and achievement motivation scale. The data were analyzed by percentage technique,simple linear regression technique, and multiple linear regression technique. The finding of this research are: 1) the general level of self concept is in middle category, 2)locus of control is in the middle range between internal locus of control and external locus of control with an average as big as 11.46,3) the general level of achievement motivation is in middle category, 4) there is an effect self concept to achievement motivation, 5) there is an effect locus of control to achievement motivation, and 6) there is an effect self concept and locus of control to achievement motivation.
\end{abstract}

Keyword: Self Concept, Locus of Control, Achievement Motivation 



\section{PENDAHULUAN}

Dari awal kehidupannya dalam rangka menuju pola pribadi yang kokoh, setiap manusia berupaya untuk hidup mandiri agar dapat bertahan hidup. Oleh sebab itu, setiap manusia memerlukan kemampuan menguasai situasi untuk menghadapi berbagai rangsangan yang dapat menghambat proses pencapaian tujuan-tujuan hidup. Salah satu kekuatan tersebut yakni motivasi. Sehubungan dengan kebutuhan hidup manusia yang mendasari timbulnya motivasi, Maslow mengungkapkan bahwa kebutuhan dasar hidup manusia terbagi atas lima tingkatan, yaitu kebutuhan fisiologis, seperti kebutuhan untuk makan, minum, berpakaian dan tempat tinggal; kebutuhan keamanan seperti kebutuhan untuk memperoleh keselamatan, keamanan, dan mendapatkan jaminan hidup; kebutuhan sosial seperti kebutuhan untuk disukai dan menyukai, dicintai dan mencintai, bergaul, berkelompok, bermasyarakat, berbangsa dan bernegara; kebutuhan akan harga diri seperti kebutuhan memperoleh kehormatan, penghormatan, pujian, prestasi, penghargaan, dan pengakuan; serta kebutuhan akan aktualisasi diri seperti kebutuhan untuk memperoleh kebanggaan dan kekaguman.

Manusia merupakan makhluk yang terus memiliki keinginan untuk pemenuhan kebutuhan diri. Apabila suatu kebutuhan telah terpenuhi, maka ia akan mencari cara untuk memenuhi kebutuhan lainnnya. Di antara kebutuhan hidup manusia, terdapat kebutuhan untuk berprestasi, yaitu dorongan untuk mengatasi hambatan, melatih kekuatan dan berusaha untuk melakukan suatu pekerjaan yang sulit dengan cara yang baik dan secepat mungkin, atau dengan perkataan lain usaha seseorang untuk menemukan atau melampaui standar keunggulan.

McClelland (2010:43) menyatakan bahwa motivasi berprestasi merupakan kecenderungan seseorang dalam mengarahkan dan mempertahankan tingkah laku untuk mencapai suatu standar prestasi.Pencapaian standar prestasi digunakan oleh mahasiswa untuk menilai kegiatan yang telah dilakukannya.Mahasiswa yang menginginkan prestasi akan menilai apakah kegiatan yang dilakukannya telah sesuai dengan standar yang ditetapkan.

Motivasi berprestasi merupakan salah satu faktor penting yang menentukan keberhasilan seseorang dalam menjalani kehidupan.Individu yang memiliki motivasi berprestasi yang baik akan memiliki usaha-usaha positif guna meraih tujuan-tujuan hidupnya, sebaliknya individu dengan motivasi berprestasi yang rendah akan terlihat dari perilaku yang ditampilkannya, yakni kurangnya gairah dan usaha dalam mencapai keinginannya.

Khusus bagi mahasiswa, motivasi berpestasi sangat berpengaruh terhadap prestasi belajar.Beberapa hasil penelitian menggambarkan bagaimana pentingnya motivasi berprestasi dalam meningkatkan hasil belajar.Diane M. Herrero (2014) dalam penelitiannya mengungkapkan bahwa motivasi berprestasi berpengaruh terhadap prestasi akademik pada mahasiswa tahun pertama. Begitu juga penelitian-penelitian lainnya yang mengungkapkan bahwa tingginya motivasi berprestasi akan menentukan prestasi belajar siswa (Mnyandu, 2001; Sudarma \&Nugraheni, 2006; Awan, Noureen \& Naz, 2011;Arvyaty, Faad Maonde \& Noho, 2016; Jeffrey \&Zein, 2017). Tentunya kondisi seperti ini sangat diharapkan, agar setiap mahasiswa dapat mencapai kesuksesan dalam bidang akademik.

Namun demikian, seperti yang penulis paparkan sebelumnya, setiap manusia memiliki perbedaan karakteristik/perilaku, termasuk pada aspek motivasi.Ada individu yang memiliki motivasi berprestasi yang baik, begitu sebaliknya.Padahal motivasi berprestasi sangat dibutuhkan setiap individu ketika berhadapan dengan permasalahan. Individu yang memiliki motivasi berprestasiakan teliti, cermat, peduli, memiliki usaha yang baik, tidak akan cepat menyerah dan tidak pasrah terhadap permasalahan yang terjadi pada dirinya. 
Penelitian yang dilakukan oleh Toding, David, Pali (2013), mengungkapkan bahwa responden lebih banyak yang memiliki motivasi berprestasi rendah dibandingkan yang memiliki motivasi berprestasi tinggi. Motivasi berprestasi rendah sebesar 68,8\%, sedangkan motivasi berprestasi tinggi sebesar 31,2\%.Begitu juga penelitian yang dilakukan oleh Harumi \& Kumoro(2016) ditemukan hasil bahwa tingkat kecenderungan siswa kelas X Kompetensi Keahlian Administrasi Perkantoran SMK Negeri 1 Wonosari berada pada kategori rendah. Rentang skor lebih dari atau sama dengan 54 sampai dengan kurang dari 67,5 masuk pada kategori rendah sebanyak 36 siswa atau (37,5\%). Khusus di IAIN Kerinci, penelitian serupa dilakukan oleh Karim (2016),bahwa motivasi berprestasi mahasiswa Fakultas Tarbiyah dan Ilmu Keguruan IAIN Kerinci berada pada ketegori yang rendah atau sebanyak $43 \%$.

Peneliti juga melakukan preeliminary research melalui observasi selama proses pembelajaran berlangsung. Peneliti mengamati bahwa masih terdapat mahasiswa yang tidak mengerjakan tugas pribadi maupun kelompok sesuai dengan kontrak antara dosen dan mahasiswa, masih ada mahasiswa yang cenderung pasif dalam proses pembelajaran, ketika penulis melaksanakan proses pembelajaran masih ada mahasiswa yang datang terlambat bahkan menjelang jam pembelajaran berakhir, beberapa mahasiswa mengeluh ketika diberikan tugas perkuliahan, ada mahasiswa yang kurang memiliki keterampilan dalam proses pembelajaran dan cenderung tidak berusaha untuk meningkatkannya, masih ada sebagian mahasiswa yang melakukan plagiat atau mencontek dalam mengerjakan tugas maupun ujian. Permasalahan-permasalahan di atas sangat bertolak belakang dengan apa yang diharapkan oleh semua pihak. Hal ini tentunya harus mendapat perhatian yang lebih dan dicari jalan keluarnya agar di kemudian hari tidak timbul permasalahan yang lain.

Menurut Heider dalam Santrock (2013),motivasi berprestasi ditentukan atas banyak faktor, di antaranya yakni karakteristik kepribadian. Burns (1979) mengemukakan bahwa salah satu unsur kepribadian yang mempengaruhi motivasi berprestasi adalah konsep diri. Apabila individu memiliki konsep diri yang positif maka ia memiliki motivasi untuk berprestasi. Beberapa hasil penelitian juga membuktikan bahwa terdapat kaitan antara kedua variabel ini (Zainalipour, Zarei \&Dayeripour, 2012; Lawrence \& Vimala, 2013;Prabadewi \& Widiasavitri, 2014; Dianto, Gistituati \& Mudjiran, 2015; Nur \& Massang, 2016).

Menurut Sutoyo, konsep diri adalah pandangan menyeluruh tentang totalitas diri, baik positif maupun negatif, mengenai dimensi fisik, psikis, sosial, pengharapan, dan penilaian terhadap diri sendiri. Hal ini terbentuk oleh persepsi diri dan lingkungan terhadap individu. Burns (1979) mengemukakan bahwa konsep diri dan prestasi akademik berkaitan erat. Konsep diri yang positif dapat membantu seseorang untuk meningkatkan kepercayaan terhadap dirinya sehingga dapat memotivasi seseorang untuk dapat menjadi lebih baik lagi.

Selain itu, menurut Rotter (1966) motivasi berprestasi juga dipengaruhi oleh locus of control.Beberapa penelitian juga telah membuktikan bahwa terdapat keterkaitan antara locus of control dan motivasi berprestasi (Labhane, Nikam, Baviskar, 2015; Nofia, Nas \& Trisnawati, 2016; Alfitami \&Rustiana, 2018).Menurut Rotters (2016), locus of control mengacu pada sejauh mana seseorang percaya bahwa apa yang terjadi pada dirinya didasarkan pada tindakan sendiri atau karakteristik pribadi versus sejauh mana orang-orang percaya bahwa penguatan atau hasil yang diterimanya adalah akibat dari kesempatan, keberuntungan, atau nasib, berada di bawah kendali orang lain yang berkuasa, atau tidak dapat diprediksi.Berdasarkan penjelasan di atas maka dapat diketahui bahwa Rotters membagi locus of control menjadi dua bentuk yakni internal locus of control dan external locus of control. Menurut Kutanis et all (2011), individu yang memiliki internal locus of control berpikir bahwa mereka memiliki peran besar untuk mempengaruhi peristiwa yang terkait dengan kehidupan. Selain itu, setiap individu menilai bahwa mereka memiliki kekuatan untuk bersikap dengan menggunakan ego positif, dan yakin bahwa mereka dapat mengarahkan hidup sesuai dengan keinginan. Selanjutnya Kutanis et all (2011) menyatakan, individu dengan external locus of 
control akan menghubungkan peristiwa yang mempengaruhi kehidupan mereka dengan pandangan bahwa peristiwa tersebut terjadi karena kebetulan, nasib, dan keberuntungan yang berada di luar kendali. Selain itu, mereka percaya bahwa peristiwa-peristiwa yang mempengaruhi kehidupan tidak dapat diprediksi dan dikendalikan.

Umumnya individu yang memiliki internal locus of controlakan lebih berorientasi kepada prestasi. Mereka memiliki tujuan dalam hidup dan berupaya dengan sungguh-sungguh untuk mencapai tujuan tersebut.Sebaliknya, external locus of control menjadikan individu pasrah pada keadaan sehingga cenderung kurang memiliki inisiatif dalam mencapai tujuan hidup.

Berdasarkan fenomena yang peneliti temui di lapangan maupun kajian terhadap riset-riset terdahulu, tampaknya topik mengenai motivasi berprestasi merupakan suatu hal yang sangat penting, dekat dan ada dalam kehidupan keseharian setiap orang, khususnya mahasiswa di IAIN Kerinci.Berdasarkan gambaran masalah dan kajian teori sebelumnya dalam penelitian ini, penulis berusaha mendeskripsikan mengenai konsep diri, locus of control, dan motivasi berprestasi, serta pengaruh kedua variabel bebas tersebut terhadap variabel terikat.

\section{KAJIAN LITERATUR}

Menurut McClelland (2010:43) motivasi berprestasi adalah dorongan untuk melakukan sesuatu hal dengan mengikuti standar kinerja yang baik serta mencoba berbagai cara untuk mencapai, dan bereaksi atas hasil sendiri. Senada dengan pendapat tersebut, Santrock (2003:474) menjelaskan bahwa motivasi berprestasi (achievement motivation) merupakan keinginan untuk menyelesaikan sesuatu, untuk mencapai suatu standar kesuksesan, dan untuk melakukan suatu usaha dengan tujuan untuk mencapai kesuksesan.McClelland (2010: 43) menambahkan bahwa semakin banyak individu berpikir dalam kondisi normal maka semakin kuat motifnya untuk mencapai sesuatu, bahkan tanpa ada instruksi dan pengalaman khusus yang dirancang untuk membangkitkan hal tersebut.

Individu yang memiliki motivasi berprestasi akan tampak dari perilaku yang ditampilkannya. McClelland (2010:43) mengemukakan bahwa ciri orang yang memiliki motivasi berprestasi adalah mereka menetapkan standar prestasi untuk diri mereka sendiri, daripada mengandalkan faktor-faktor dari luar, dan mereka harus berusaha lebih keras untuk mencapai standar yang mereka tetapkan untuk diri mereka sendiri. McClelland (2010) menambahkan individu yang memiliki motivasi berprestasi yang tinggi menunjukkan karakteristik perilaku kewiraswastaan yang sukses, terus berusaha untuk memperbaiki proses dan prosedur, kemauan dan memperhitungkan risiko, secara aktif mencari informasi mengenai tindakan mereka, kecenderungan untuk bertanggung jawab atas perilakunya. Menurut Makmun (2001:40), ada beberapa indikator individu yang memiliki motivasi berprestasi tinggi, antara lain: 1) durasinyakegiatan (berapa lama kemampuan penggunaan waktunya untuk melakukan kegiatan); 2) frekuensinyakegiatan (berapa sering kegiatan itu dilakukan dalam periode tertentu); 3) persistensinya (ketepatan dan ketekatannya) pada tujuan kegiatan; 4) ketabahan, keuletan, dan kemampuannya dalam menghadapi rintangan dan kesulitan untuk mencapai tujuan; 5) devosi(pengabdian) dan pengorbanan (uang, tenaga, pikiran, bahkan jiwanya) untuk mencapai tujuan; 6) tingkat aspirasinya (maksu, rencana, cita-cita, sasaran, atau target, dan idolanya) yang hendak dicapai dengan kegiatan yang dilakukan; 7) tingkatan kualifikasi pretasi atau produk output yang sudah dicapai dari kegiatannya (berapa banyak, memadai, atau tidak, memuaskan atau tidak); dan 8) arah sikapnya terhadap sasarankegiatan (like or dislike; positif atau negatif).

Kajian mengenai motivasi berprestasi telah banyak dilakukan oleh peneliti-peneliti terdahulu.Awan, Noureen \& Naz (2011) mengemukakan melalui hasil penelitiannya bahwa motivasi berprestasi akademik dan konsep diri berpengaruh terhadap prestasi akademik pada 
mata pelajaran Bahasa Inggris dan Matematika.Mnyandu (2001), melakukan penelitian mengenai hubungan determinasi diri, motivasi berprestasi dan prestasi akademik bahwa terdapat hubungan antara tiga variabel tersebut. Selanjutnya penelitian Arvyaty, Faad Maonde \& Noho (2016) ditemukan hasil bahwa terdapat pengaruh motivasi berprestasi terhadap prestasi belajar matematika siswa SMA Negeri dan SMA SWASTA di kota Kendari. Ketut Sudarma \& Fitria Nugraheni (2006) juga melakukan penelitian mengenai motivasi berprestasi, bahwa terdapat pengaruh yang positif dan signifikan antara Motivasi berprestasi dan Strategi Belajar Efektif Terhadap Prestasi Belajar Akuntansi Kasus Pokok Bahasan Laporan Keuangan Perusahaan Dagang pada siswa Kelas II Semester 2 di SMA Negeri 14 Semarang Tahun Pelajaran 2004/2005. Senada dengan penelitian tersebut, Jeffrey \&Zein (2017) mengemukakan melalui penelitiannya bahwa terdapat pengaruh motivasi berprestasi terhadap hasil belajar.

Menurut McClelland (2010:39),motivasi berprestasi dikendalikan oleh banyak faktor,di antaranya persetujuan sosial, kekuasaan, pengetahuan dan kemampuan. Manafi, Mohammadi \&Hejazi (2015), mengemukakan bahwa faktor-faktor yang mempengaruhi motivasi berprestasi antara lain usaha, berorientasi pada tujuan, ketekunan, keahlian dan kemampuan. Selanjutnya penelitian yang dilakukan Nasreen \& Naz (2013) bahwa faktor-faktor yang mempengaruhi motivasi berprestasi siswa antara lain keterlibatan orang tua, gaya mengajar guru, status sosial ekonomi, tekanan teman sebaya. Motivasi berprestasi juga ditentukan atas karakteristik kepribadian (Heider dalam Santrock, 2003: 476).Di antara unsur kepribadian yang mempengaruhi motivasi berprestasi adalah konsep diri (Burns, 1979:356).Penelitian yang dilakukan Lawrence \& Vimala (2013) mengemukakan bahwa terdapat hubungan yang positif antara konsep diri dan motivasi berprestasi.Nur \& Massang (2016) melalui penelitiannya juga mengungkapkan terdapat pengaruh konsep diri terhadap motivasi berprestasi.Selanjutnya Prabadewi \& Widiasavitri (2014) melakukan penelitian terhadap penghuni panti asuhan di Denpasar, dengan temuan terdapat hubungan antara konsep diri akademik dengan motivasi berprestasi. Begitu juga penelitian yang dilakukan Dianto, Gistituati \& Mudjiran (2015) bahwa terdapat pengaruh konsep diri terhadap motivasi berprestasi, serta penelitian yang dilakukan Zainalipour, Zarei \& Dayeripour bahwa (2012) bahwa academic self-esteem, mental health and academic self-concept berpengaruh terhadap motivasi berprestasi. Namun setiap individu memiliki perbedaan terkait faktor yang paling dominan.

Menurut Santrock, (2007:183) konsep diri merujuk pada evaluasi diri yang menyangkut bidang-bidang tertentu dari diri. Remaja melakukan evaluasi diri dalam berbagai bidang akademis, atletik, penampilan fisik, dan sebagainya.Intinya konsep diri merujuk pada evaluasi pada bidangbidang tertentu.Konsep diri didefinisikan oleh Eccles et all (2005) sebagai pandangan kolektif tentang diri sendiri dalam serangkaian persepsi spesifik domain multidimensional. Persepsi ini didasarkan pada pengetahuan diri dan evaluasi nilai atau kemampuan seseorang yang terbentuk melalui pengalaman dan interpretasi lingkungan. Konsep diri membahas sisi yang lebih faktual dalam hidup individu, seperti mengetahui apa yang mereka sukai atau bagaimana cara individu berpikir. Burns (1979:73) menjelaskan bahwa konsep diri merupakan konseptualisasi individu mengenai pribadinya sendiri yang dipandang dari kondisi emosional dan penilaiannya terhadap pengetahuan faktualnya. Burns (1979:74),mengatakan bahwakonsep diri merupakan kombinasi dari: 1) citra diri - apa yang dilihat seseorang ketika dia melihat kepada dirinya sendiri; 2) intensitas afektif - seberapa kuat seseorang merasakan tentang bermacam-macam segi ini; 3) evaluasi diri-apakah seseorang mempunyai pendapat menyenangkan atau tidak menyenangkan tentang bermacam-macam dari image itu; dan 4) predisposisi tingkah laku-apa kemungkinan besar diperbuat seseorang di dalam memberi respon kepada evaluasinya tentang dirinya sendiri.konsep diri terdiri dari perasaan dan pikiran tentang kekuatan dan kelemahan, kemampuan dan keterbatasan, dan aspirasi dan pandangan dunia (Black, 1999). Devito (2013:55) mengemukakan bahwa konsep diri berkembang dari setidaknya empat sumber: (1) citra yang dimiliki orang lain dan yang mereka ungkapkan kepada diri, (2) perbandingan yang dibuat antara 
kita dan orang lain, (3) budaya, dan (4) cara individu menafsirkan dan mengevaluasi pemikiran dan perilaku.

Faktor lain yang mempengaruhi motivasi berprestasi adalah locus of control. Hal ini didasarkan atas kajian teori dan hasil-hasil penelitian terdahulu.Kajian yang dilakukan Nofia, Nas \& Trisnawati (2016), bahwa terdapat pengaruh locus of control terhadap motivasi berprestasi.Selanjutnya penelitian Alfitami \&Rustiana (2018), dengan temuan terdapat pengaruh locus of control terhadap motivasi berprestasi.Temuan yang sama juga dikemukakan Labhane, Nikam, Baviskar (2015) bahwa terdapat hubungan antara kedua variabel tersebut.

Konsep locus of control pertama kali dikembangkan oleh Rotter pada tahun 1966 yang memberikan gambaran pada keyakinan seseorang mengenai sumber penentu perilaku. Menurut Spector (dalam Munir \& Sajid, 2010:78), locus of control didefinisikan sebagai kecenderungan individu untuk percaya bahwa ia mampu mengendalikan peristiwa dalam kehidupan (internal) atau bahwa kontrol peristiwa berada di luar diri (eksternal). Raven (2000:14) mengemukakan bahwa locus of control merupakan kontrol perilaku individu atas faktor-faktor dari dalam diri (internal locus of control) atau di luar diri (external locus of control). Berdasarkan berbagai definisi di atas maka dapat ditarik kesimpulan bahwa locus of control adalah keyakinan seseorang tentang keterkaitan antara usaha dan hasil yang diterima, sehingga mereka mampu mengontrol peristiwa dalam hidupnya.

Orientasi locus of control dibagi menjadi dua, yaitu internal locus of control dan external locus of control.Menurut Rotter (1989), internallocus of control mengacu pada sejauh mana seseorang mengharapkan bahwa penguatan atau hasil dari perilaku mereka tergantung pada perilaku mereka sendiri atau karakteristik pribadinya, dan external locus of control sejauh mana seseorang mengharapkan bahwa penguatan atau hasil merupakan fungsi dari kesempatan, keberuntungan, atau nasib, berada di bawah kendali kekuatan orang lain, atau tidak terduga. Menurut Kutanis, et all (2011),individu dengan external locus of control akan menghubungkan peristiwa yang mempengaruhi hidup mereka dengan keberuntungan dan nasib yang berada di luar kendali mereka. Selanjutnya Zimbardo (dalam Neill, 2006) mengemukakan orientasi external locus of control adalah meyakini bahwa perilakunya dikendalikan oleh nasib, keberuntungan atau keadaan eksternal lainnya.Berdasarkanbeberapa pengertian di atas, dapat disimpulkan bahwa internallocus of control adalah keyakinan individu bahwa sumber penentu dariperistiwa atau kejadian dalam hidupnya dipengaruhi oleh usaha dan tingkahlakunya sendiri. Sebaliknya individu dengan eksternal locus of controlakan memandang bahwa segala bentuk usahanya dalam mencapai sesuatu dipengaruhi oleh nasib dan keberuntungan (faktor luar).

Levenson (1981:16) mengelompokan orientasi locus of control sebagai berikut: 1) internality (I), yakni individu merasa yakin bahwa persitiwa yang dialami dalam kehidupan mereka terutama ditentukan oleh kemampuan usaha sendiri; 2) powerful others $(\mathrm{P})$, yakni individu meyakini bahwa kehidupan mereka ditentukan oleh orang yang lebih berkuasa;dan 3) chance (C), yakni individu meyakini bahwa kehidupan dan kejadian yang dialami sebagian besar ditentukan takdir, nasib dan keberuntungan dan kesempatan.

Crider (dalam Ghufron \& Risnawita, 2010:68) memaparkan karaktersitik internal locus of control sebagai berikut: 1) suka bekerja keras. Orang yang memiliki internal locus of control yang baik pada umumnya bekerja keras dalam mencapai sesuatu. Dalam artian ia tidak pasrah dan mudah putus asa; 2) memiliki inisiatif, yakni suatu keadaan di mana dengan kehendak sendiri tanpa paksaan seseorang melakukan hal-hal tertentu untuk mencapai tujuan;3) selalu berusaha menemukan pemecahan masalah. Pemecahan masalah merupakan sesuatu yang harus dicari yakni dengan menggunakan langkah-langkah tertentu; 4) selalu mencoba untuk berfikir seefektif mungkin. Ketika dihadirkan atau dihadapi permasalahan maka segera ia berfikir untuk 
menemukan penyelesaian masalahnya; dan 5) selalu memiliki persepsi bahwa usaha harus dilakukan jika ingin berhasil, hal ini mengindikasikan bahwa orang dengan internal locus of controlmemiliki asumsi bahwa jika ingin mencapai sesuatu maka harus berusaha. Dengan kata lain memiliki motivasi untuk melakukan sesuatu dalam mencapai apa yang diinginkan.

Selanjutnya Crider (dalam Ghufron \& Risnawita, 2010:68) juga mengemukakan ciri-ciri individu yang berorientasi external locus of control, antara lain: 1) kurang memiliki inisiatif, yakni individu yang kurang memiliki dorongan untuk melakukan sesuatu dengan dorongannya sendiri; 2) mempunyai harapan bahwa ada sedikit korelasi antara usaha dan kesuksesan. Ini merupakan pandangan yang kurang tepat. Usaha sangat menentukan keberhasilan dan kesuksesan yang ingin dicapai; 3) kurang berusaha karena percaya bahwa faktor luar yang mengontrol, individu beranggapan bahwa kesuksesan maupun pencapaian akan sesuatu hanya akan dipengaruhi oleh faktor luar, seperti harapan atau ketergantungan terhadap orang lain; dan 4) kurang mencari informasi untuk memecahkan masalah, yakni tidak aktif dan keinginan sendiri untuk mencari informational support dalam rangka memecahkan masalahnya

\section{METODOLOGI}

Penelitian ini menggunakan pendekatan kuantitatif dengan metode deskriptif dan korelasional. Adapun variabel dalam penelitian ini terdiri dari konsep diri $\left(\mathrm{X}_{1}\right)$ dan locus of control $\left(\mathrm{X}_{2}\right)$ yang merupakan variabel bebas dan motivasi berprestasi $(\mathrm{Y})$ yang merupakan variabel terikat.

Populasi dalam penelitian ini adalah seluruh mahasiswa BKI IAIN Kerinci angkatan 2013 yang berjumlah 100 orang.Metode penarikan sampel dalam penelitian ini dengan menggunakan simplerandom sampling.Metode ini digunakan agar setiap individu memiliki kesempatan yang sama untuk dijadikan sampel. Berdasarkan metode tersebut diperoleh sampel sebanyak 80mahasiswa.

Dalam penelitian ini, peneliti mengadaptasi skala Tennessee Self Concept Scale oleh William H. Fitts yang dimodifikasi oleh Julia Raymod Lorenz.Untuk mengungkap locus of control digunakan inventory Rotters Internal-External Locus of Control (I-E Scale) yang berisi 29 item, di mana terdapat 6 filler item, sehingga jumlah total item yang dapat diskor sebanyak 23 item. Responden diminta untuk memilih salah satu pernyataan yang sesuai dengan asumsi responden.Inventori ini telah diadaptasi oleh Marjohan.Sedangkan untuk mengukur motivasi berprestasi, peneliti akan menggunakan skala/instrumen motivasi berprestasi yang telah disusun oleh Donal di mana instrumen tersebut telah melewati uji validitas konstruk dan konten serta reliabilitas.

Penetapan kriteria penilaian menggunakannorma kategorisasi khusus. Untuk mengetahui kontribusi variabel-variabel bebas terhadap variabel terikat, dianalisa dengan menggunakan teknik analisa regresi sederhana dan analisis regresi ganda. Analisis data menggunakanprogram SPSS 17 for windows.

\section{TEMUAN}

\section{Hasil Penelitian}

Data yang diperoleh dari hasil pengadministrasian terhadap mahasiswa yang layak diolah yaitu sebanyak 80 data. Data penelitian ini meliputi tiga variabel, yaitu: variabel konsep diri $\left(\mathrm{X}_{1}\right)$, locus of control $\left(\mathrm{X}_{2}\right)$ dan variabel motivasi berprestasi $(\mathrm{Y})$. Deskripsi mengenai motivasi berprestasi mahasiswa dapat dilihat pada tabel berikut: 
Tabel 1.Distribusi Frekuensi dan Persentase Motivasi Berprestasi Mahasiswa

\begin{tabular}{clcc}
\hline Interval Skor & \multicolumn{1}{c}{ Kategori } & Frekuensi (f) & Persentase $(\%)$ \\
\hline$\geq 79$ & Sangat Tinggi (ST) & 15 & 18,75 \\
$73-78$ & Tinggi (T) & 23 & 28,75 \\
$66-72$ & Sedang (S) & 16 & 20 \\
$60-65$ & Rendah (R) & 21 & 26,25 \\
$\leq 59$ & Sangat Rendah (SR) & 5 & 6,25 \\
\hline & \multicolumn{1}{c}{ Total } & 80 & 100 \\
\hline
\end{tabular}

Dari tabel $1 \mathrm{di}$ atas terlihat bahwa dari jumlah keseluruhan sampel yang berjumlah 80mahasiswa, sebagian besar motivasi berprestasimahasiswa berada pada kategori tinggi ( $\mathrm{T}$ ) dengan jumlah frekuensi 23mahasiswa atau 28,75\%,selanjutnya disusul pada kategori rendah (R) dengan jumlah frekuensi 21 mahasiswa yang dapat dipersentasekan sebesar26,25\%, kategori sangat tinggi (ST) dengan frekuensi sebanyak 15 mahasiswa atau 18,75\%, kategori sedang (S) dengan jumlah frekuensi 16mahasiswa yang dapat dipersentasekan sebesar20\%, dan sangat rendah (SR) dengan jumlah frekuensi 5 mahasiswa atau6,25\%.

Pada tabel berikut ini akan dipaparkan rata-rata skor total pada variabel motivasi berprestasi:

Tabel 2.Rata-rata Skor Total Variabel Motivasi Berprestasi

\begin{tabular}{ccc}
\hline Total Skor $\left(\sum\right)$ & Rata-rata $($ Mean $)$ & Standar Deviasi (SD) \\
\hline 5659 & 70,737 & 7,96 \\
\hline
\end{tabular}

Berdasarkan tabel di atas dapat diketahui bahwa total skor pada variabel motivasi berprestasi sebesar 5659, rata-rata skor 70,737 dan standar deviasi sebesar 7,96. Dari tabel tersebut dapat diketahui motivasi berprestasi mahasiswa secara umum berada pada kategori sedang.

Deskripsi mengenai konsep diri mahasiswadapat dilihat pada tabel berikut:

Tabel 3.Distribusi Frekuensi dan Persentase Konsep Diri

\begin{tabular}{clcc}
\hline Interval Skor & \multicolumn{1}{c}{ Kategori } & Frekuensi (f) & Persentase $(\%)$ \\
\hline$\geq 217$ & Sangat Tinggi (ST) & 5 & 6,25 \\
$209-216$ & Tinggi (T) & 17 & 21,25 \\
$202-208$ & Sedang (S) & 20 & 25 \\
$195-201$ & Rendah (R) & 21 & 26,25 \\
$\leq 194$ & Sangat Rendah (SR) & 17 & 21,25 \\
\hline & \multicolumn{1}{c}{ Total } & 80 & 100 \\
\hline
\end{tabular}

Dari keseluruhan sampel yang berjumlah 80 mahasiswa, sebagian besar konsep diri mereka berada kategori rendah (R) dengan jumlah frekuensi 21 mahasiswa atau 26,25\%, selanjutnya kategori sedang (S) dengan jumlah frekuensi sebanyak 20 mahasiswa yang dapat dipersentasekan sebesar 25\%, selanjutnya disusul pada kategori tinggi (T) dan sangat rendah (SR) dengan jumlah frekuensi 17 mahasiswa yang dapat dipersentasekan dengan nilai $21.25 \%$, dan kategori sangat tinggi (ST) dengan frekuensi sebanyak 5 mahasiswa atau dapat dipersentasekan sebesar 6,25\%.

Pada tabel berikut ini akan dipaparkan rata-rata skor total pada variabel konsep diri:

Tabel 4.Rata-rata Skor Total Variabel Konsep Diri

\begin{tabular}{ccc}
\hline Total Skor $(\Sigma)$ & Rata-rata (Mean) & Standar Deviasi (SD) \\
\hline 16205 & 202,562 & 8,45 \\
\hline
\end{tabular}


Berdasarkan tabel di atas dapat diketahui bahwa total skor pada variabel motivasi berprestasi sebesar 16205, rata-rata skor 202,562 dan standar deviasi sebesar 8,45. Dari tabel tersebut dapat diketahui konsep diri mahasiswa secara umum berada pada kategori sedang.

Deskripsi mengenai locus of control mahasiswa dapat dilihat pada Tabel berikut:

Tabel 5.Mean dan Standar Deviasi pada Variabel Locus of Control

\begin{tabular}{ccccccc}
\hline \multirow{2}{*}{$\mathbf{N}$} & Min & Max & Total & Mean & SD \\
\cline { 2 - 6 } & 6 & 16 & 835 & 10.44 & 2.07 \\
\hline 80 & & &
\end{tabular}

Dari Tabel 6 di atas terlihat bahwa dari jumlah keseluruhan sampel yang berjumlah 80 mahasiswa, diperoleh skor minimal 6, skor maksimal 16, rata-rata skor sebesar 10,44 dan SD sebesar 2.07. Berdasarkan hasil perhitungan tersebut, maka dapat diketahui bahwa skor rata-rata perolehan locus of control cenderung berada pada rentang pertengahan antara internal locus of control dan external locus of control jika dilihat dari nilai tengah (median) sebesar 11.5.

Sebelum melakukan uji hipotesis, terlebih dahulu dilakukan uji persyaratan analisis, di mana data yang diperoleh dari lapangan telah lulus uji normalitas, linearitas, dan multikolinearitas. Pengujian normalitas data dengan menggunakan teknik analisa Kolmogorov -Smirnov dengan koreksi Liliefors, menggunakan ketetapan alpha $(\alpha)$ 0.05.Berdasarkan pengolahan data diperoleh hasil uji normalitas sebagai berikut.

Tabel 6. Uji Normalitas Data Motivasi Berprestasi, Konsep Diri dan Locus of Control

\begin{tabular}{cccc}
\hline No & Etnis & Asymp. Sig & Ket. \\
\hline 1 & Motivasi Berprestasi & 0,061 & Normal \\
2 & Konsep Diri & 0.200 & Normal \\
3 & Locus of Control & 0,065 & Normal \\
\hline
\end{tabular}

Berdasarkan data pada tabel 6 di atas, terlihat bahwa keseluruhan Asymp.Sig lebih besar dari 0.05, ini berarti data motivasi berprestasi, konsep diri dan locus of control berdistribusi normal.

Uji linearitas dalam penelitian ini akan dipaparkan pada tabel berikut ini :

Tabel 7. Uji Linearitas Data Motivasi Berprestasi, Konsep Diri dan Locus of Control

\begin{tabular}{clccc}
\hline No & \multicolumn{1}{c}{ Variabel } & Deviation from linearity & Taraf Signifikansi & Kesimpulan \\
\hline 1 & $\begin{array}{l}\text { Konsep diri X } \\
\text { Motivasi Berprestasi Y }\end{array}$ & 0.199 & 0.05 & Linear \\
2 & $\begin{array}{l}\text { Locus of control X } \\
\text { Motivasi berprestasi Y }\end{array}$ & 0.673 & 0.05 & Linear \\
\hline
\end{tabular}

Berdasarkan hasil analisapada tabel di atas, bahwa hubungan semua variabel independent dengan variabel dependent adalah linear atau searah. Deviation from linearityuntuk konsep diri dengan motivasi berprestasi 0.199 dan locus of control dengan motivasi berprestasi 0.673.Jika dibandingkan dengan nilai Sig. $>0.05$ maka nilai deviation from linearity $0.0199>0.05$ dan $0,673>0.05$, sehingga dapat disimpulkan linear.

Untuk melihat kemungkinan terjadinya multikolinearitas digunakan bantuan SPSS.Apabila nilai VIFs 10 atau lebih menjadi aturan praktis untuk menyimpulkan VIF untuk terlalu besar, sehingga disimpulkan terjadi multikolinearitas. Berdasarkan perhitungan diperoleh hasil sebagai berikut: 
Tabel 8. Hasil Uji Multikolinearitas antara Variabel Konsep Diri dan Locus of Control

\begin{tabular}{cccccccccc}
\hline \multirow{2}{*}{ Model } & & \multicolumn{2}{c}{$\begin{array}{c}\text { Unstandardized } \\
\text { Coefficients }\end{array}$} & \multicolumn{2}{c}{$\begin{array}{c}\text { Standardized } \\
\text { Coefficients }\end{array}$} & t & Sig. & \multicolumn{2}{c}{$\begin{array}{c}\text { Collinearity } \\
\text { Statistics } \\
\text { Tolerance }\end{array}$} \\
& & \multicolumn{2}{c}{ B VIF } \\
\hline \multirow{2}{*}{1} & (Constant) & 36.438 & 21.020 & & 1.734 & .087 & & \\
& KonsepDiri & .225 & .099 & .239 & 2.267 & .026 & .989 & 1.011 \\
& LOC & -1.088 & .405 & -.283 & -2.684 & .009 & .989 & 1.011 \\
\hline
\end{tabular}

Berdasarkan tabel 8, dapat diperoleh nilai VIF sebesar 1.011, sehingga diketahui bahwa $1.011<$ 10.Dengan demikian tidak terjadi multikolinearitas antara variabel konsep diri dengan locus of control.

Adapun hipotesis $(\mathrm{Ha})$ dalam penelitian ini, yaitu:

1. Terdapat pengaruh konsep diri terhadap motivasi berprestasimahasiswa.

2. Terdapat pengaruh locus of controlterhadap motivasi berprestasimahasiswa.

3. Terdapat pengaruh konsep diri dan locus of control terhadap motivasi berprestasi mahasiswa.

Untuk menjawab hipotesis pertama, dilakukan analisa korelasi antara konsep diri dengan motivasi berprestasi yang menghasilkan koefisien korelasi sebesar rx1y $=0,268$. Secara jelas uji keberartian koefisien korelasi disajikan pada tabel berikut ini.

Tabel 9.Hasil Analisa Korelasi Variabel Konsep Diri $\left(\mathrm{X}_{1}\right)$ dengan Variabel Motivasi Berprestasi(Y)

\begin{tabular}{ccccc}
\hline Model & $\mathrm{R}$ & $\mathrm{R}$ Square & Adjusted R Square & Std. Error of the Estimate \\
\hline 1 & 0.268 & .072 & .060 & 7.721 \\
\hline
\end{tabular}

Pada tabel 9terlihat bahwa nilai r sebesar 0,268, yang menunjukkan koefisien korelasi positifantara konsep diridengan motivasi berprestasi. Nilai $\mathrm{r}$ Square sebesar 0,72 menunjukkan bahwa besarnya pengaruh konsep diriterhadapmotivasi berprestasi sebesar 7,2\%.Selanjutnya untuk mengetahui hasil analisis regresi sederhana dapat dilihat pada tabel berikut:

Tabel 10.Hasil Analisa Regresi Sederhana Variabel Konsep Diri $\left(\mathrm{X}_{1}\right)$ terhadap Variabel Motivasi Berprestasi (Y)

\begin{tabular}{|c|c|c|c|c|c|c|}
\hline & \multirow{2}{*}{ Model } & \multicolumn{2}{|c|}{ Unstandardized Coefficients } & \multirow{2}{*}{$\begin{array}{c}\text { Standardized } \\
\text { Coefficients } \\
\text { Beta }\end{array}$} & \multirow[t]{2}{*}{$\mathrm{T}$} & \multirow{2}{*}{ Sig. } \\
\hline & & $\mathrm{B}$ & Std. Error & & & \\
\hline \multirow[t]{2}{*}{1} & (Constant) & 19.509 & 20.834 & & .936 & .352 \\
\hline & KonsepDiri & .253 & .103 & .268 & 2.461 & .016 \\
\hline
\end{tabular}

Dari tabel di atasdiketahui thitungsebesar2,461pada taraf signifikan 0,016. Dikarenakan nilai signifikansi $0,016<0,05$, artinya koefisien regresi signifikan. Dapat disimpulkan bahwa terdapat pengaruh konsep diri terhadap motivasi berprestasi.

Selanjutnya untuk menjawab hipotesis kedua, dilakukan analisa korelasi antaralocus of control $\left(\mathrm{X}_{2}\right)$ denganmotivasi berprestasi $(\mathrm{Y})$.Hasil perhitungan koefisien korelasi dan regresi sederhana dapat dilihat pada tabel berikut: 
Tabel 11.Hasil Analisa Korelasi Locus of Control $\left(\mathrm{X}_{2}\right)$ dengan Motivasi Berprestasi $(\mathrm{Y})$

\begin{tabular}{ccccc}
\hline Model & R & R Square & Adjusted R Square & Std. Error of the Estimate \\
\hline 1 & $-0.308^{a}$ & .095 & .083 & 7.626 \\
\hline
\end{tabular}

Pada tabel 11di atas terlihat bahwa nilai $\mathrm{r}$ sebesar -0,308 menunjukkan koefisien korelasi negatif antara locus of control dengan motivasi berprestasi. Nilai $r$ Square sebesar 0,95 menunjukkan bahwa besarnya pengaruh locus of controlterhadapmotivasi berprestasi sebesar 9,5\%. Selanjutnya untuk mengetahui hasil analisis regresi sederhana dapat dilihat pada Tabel berikut:

Tabel 12.Hasil Analisa Regresi Sederhana Locus of Control $\left(\mathrm{X}_{2}\right)$ terhadap Variabel Motivasi Berprestasi( $(\mathrm{Y})$

\begin{tabular}{clllll}
\hline Model & \multicolumn{2}{c}{ Unstandardized Coefficients } & $\begin{array}{c}\text { Standardized } \\
\text { Coefficients } \\
\text { Beta }\end{array}$ & T & Sig. \\
& B & Std. Error & & & 18.874 \\
\hline 1 (Constant) & 83.084 & 4.402 & -.308 & -2.859 & .000 \\
LOC & -1.183 & .414 & 005 \\
\hline
\end{tabular}

Dari tabel 12 juga diketahui thitung sebesar-2,859pada taraf signifikan 0,005, maka Ha diterima, artinya koefisien regresi signifikan. Dapat disimpulkan bahwa terdapat pengaruh locus of controlterhadapmotivasi berprestasi.

Selanjutnya untuk menjawab hipotesis ketiga dilakukan melalui analisa korelasi antara konsep diri (X1) dan locus of control $\left(\mathrm{X}_{2}\right)$ denganmotivasi berprestasi (Y).Hasil perhitungan koefisien korelasi dan regresi ganda dapat dilihat pada tabel berikut:

Tabel 13. Hasil Analisa Korelasi Variabel Konsep Diri $\left(\mathrm{X}_{1}\right)$ dan Locus of Control $\left(\mathrm{X}_{2}\right)$ dengan Motivasi Berprestasi $(Y)$

\begin{tabular}{ccccc}
\hline Model & $\mathrm{R}$ & R Square & $\begin{array}{c}\text { Adjusted } \\
\text { R Square }\end{array}$ & Std. Error of the Estimate \\
\hline 1 & 0.389 & .151 & .129 & 7.431 \\
\hline
\end{tabular}

Pada tabel 13 di atas, terlihat bahwa nilai $\mathrm{R}$ sebesar 0,389 menunjukkan koefisien korelasi antara konsep diri dan locus of control dengan motivasi berprestasi. Nilai $\mathrm{R}$ Square sebesar 0,151 menunjukkan bahwa besarnya pengaruh konsep diri dan locus of controlterhadapmotivasi berprestasi sebesar 15,1\%. Selanjutnya untuk membuktikan hipotesis penelitian di atas, dilakukan uji signifikansi koefisien regresi ganda seperti yang tertera pada tabel berikut:

Tabel 14. Hasil Ringkasan Anova untuk Uji Signifikansi Konsep Diri $\left(\mathrm{X}_{1}\right)$ dan Locus of Control $\left(\mathrm{X}_{2}\right)$ terhadap Motivasi Berprestasi $(\mathrm{Y})$

\begin{tabular}{lccccc}
\hline Model & Sum of Squares & df & Mean Square & F & Sig. \\
\hline Regression & 759.085 & 2 & 379.542 & 6.873 & $.002^{\mathrm{a}}$ \\
Residual & 4252.403 & 77 & 55.226 & & \\
Total & 5011.488 & 79 & & & \\
\hline
\end{tabular}

Uji signifikansi ini bertujuan untuk menjelaskan apakah variasi nilai variabel bebas atau variabel independent dapat menjelaskan variasi nilai dependent dengan mengunakan besaran nilai F. Tabel 14 di atas menjelaskan apakah variasi nilai variabel bebas (konsep diri dan locus of control) dapat menjelaskan variabel terikat (motivasi berprestasi) dengan melihat besarnya nilai $F_{\text {hitung. }}$ Nilai $F_{\text {hitung }}$ diperoleh sebesar 6,873 dan signifikansi 0,002. Dapat disimpulkan, bahwa koefisien regresi ganda yang diperoleh dalam penelitian ini signifikan. 
Temuan ini menolak hipotesis nol, yakni tidak terdapat pengaruh konsep diri $\left(\mathrm{X}_{1}\right)$ dan locus of control $\left(\mathrm{X}_{2}\right)$ terhadap motivasi berprestasi $(\mathrm{Y})$. Konsekuensinya $\mathrm{Ha}$ diterima, yaitu terdapat pengaruh konsep diri $\left(\mathrm{X}_{1}\right)$ dan locus of control $\left(\mathrm{X}_{2}\right)$ terhadap motivasi berprestasi $(\mathrm{Y})$.

\section{PEMBAHASAN}

Berdasarkan hasil pengujian yang telah diuraikan, maka terbukti bahwa konsep diri dan locus of control berpengaruh terhadap motivasi berprestasi. Pada bagian berikut akan dijelaskan pembahasan untuk masing-masing variabel yang dikaji dalam penelitian.

\section{Motivasi Berprestasi}

Temuan penelitian menunjukkan bahwa secara keseluruhan, motivasi berprestasi mahasiswa berada dalam kategori sedang dengan rata-rata persentase sebesar 70,737\%. Motivasi berprestasi tentunya sangat dibutuhkan setiap individu dalam kehidupannya. Individu yang memiliki motivasi berprestasi akan teliti, cermat, peduli, memiliki usaha yang baik, tidak akan cepat menyerah dan tidak pasrah terhadap keadaan ketika memiliki tujuan-tujuan tertentu. Bimbingan dan pembinaan yang diberikan bertujuan agar individu memiliki motivasi berprestasi yang tinggi. Motivasi berprestasi yang tinggi dapat menjadikan seseorang menjadi sukses dan bahagia. Sukada, Sadia \&Yudana (2013) melakukan penelitian mengenai pengaruh motivasi berprestasi terhadap prestasi belajar diperoleh hasil bahwa motivasi berpengaruh pada pencapaian prestasi akademik. Begitu juga penelitian yang dilakukan oleh Donal (2015) bahwa motivasi berprestasi berkontribusi terhadap arah perencanaan karir. Dalam artian bahwa individu yang memiliki motivasi berprestasi tinggi cenderung memiliki arah perencanaan karir yang baik pula. Bahkan dalam situasi lanjut, motivasi berprestasi memberikan pengaruh kepada kinerja.

Mahasiswa hendaknya menunjukkan karakteristik memiliki motivasi berprestasi, antara lain: 1) berorientasi sukses dan lebih percaya diri dalam mengapai prestasi yang berhubungan dengan tugas-tugas; 2) mengarahkan tujuan dan memiliki sikap yang berorientasi masa depan; 3) menyukai tugas-tugas yang memiliki tingkat kesulitan sedang; 4) tidak suka membuang-buang waktu; 5) tahan dalam mengerjakan tugas; dan 6) lebih menyakini dengan kemampuan sendiri daripada menyukai orang lain sebagai teman untuk menyelesaikan tugas, sehingga motivasi berprestasi lebih tinggi dari motivasi afliasi (Heckhansen dalam Amirah Diniaty, 2001). Dengan hasil temuan ini, maka perlu kiranya dilakukan upaya untuk meningkatkan dan mempertahankan motivasi berprestasi yang baik pada mahasiswa.Konselor Unit Pelayanan Bimbingan dan Konseling IAIN Kerinci sebagai pelaksana kegiatan pelayanan konseling dapat menyusun program yang dapat dioperasionalkan dan/atau realistis untuk dilaksanakan terkait dengan upaya peningkatan variabel yang dimaksud.Dengan program intervensi yang tepat, diharapkan mahasiswa dapat memiliki motivasi untuk berprestasi.

\section{Konsep Diri}

Hasil analisa menunjukkan bahwa rata-rata skorkonsep diri mahasiswa sebesar202,562.Berdasarkan temuan tersebut, maka dapat diketahui bahwa pada umumnya mahasiswa berada pada kategori sedang. Konsep diri merupakan penilaian seseorang terhadap dirinya sendiri yang memiliki dua dimensi, yakni positif maupun negatif. Dimensi ini akan mempengaruhi bagaimana cara individu memperlakukan dirinya sendiri maupun ketika berhubungan dengan orang lain. Oleh sebab itu, semakin baik konsep diri individu maka tidak sulit baginya untuk mencapai kehidupan yang efektif, begitu juga sebaliknya, bahwa semakin rendah konsep diri maka akan menjadi penghambat individu untuk mencapai kehidupan yang efektif. 
Penelitian yang dilakukan oleh Pardede (2008)berkenaan dengan konsep diri anak jalanan usia remaja, ditemukan hasil bahwa umumnya konsep diri yang dimiliki mereka negatif. Hal tersebut dipengaruhi oleh beberapa faktor, yakni orangtua, kawan sebaya, dan masyarakat. Begitu pula penelitian yang dilakukan oleh Purwanti et all (2000), mengenai konsep diri perempuan marginal, bahwa umumnya konsep diri anak jalanan (perempuan) cenderung lebih rendah/negatif. Namun demikian, tidak semua orang yang berada dalam lingkungan yang tidak menyenangkan akan memiliki konsep diri yang negatif. Penelitian yang dilakukan oleh Chiktia Irma Oktaviani (2014), konsep diri anak yang mengalami broken home cenderung mengarah kepada positif.

Perbedaan temuan hasil penelitian merupakan hal yang wajar karena konsep diri dipengaruhi atas banyak faktor (Pardede, 2008).Menurut Pujijogyanti (1988) beberapa faktor yang mempengaruhi perkembangan konsep diri yaitu: (a) perasaan citra diri, (b) peranan jenis kelamin, (c) peranan perilaku orang tua, dan (d) peranan faktor sosial. Tidak jauh berbeda dengan pendapat tersebut, Puspasari (2007) mengemukakan bahwa konsep diri banyak terpengaruh oleh faktor eksternal, antara lain: (a) pengaruh keterbatasan ekonomi, (b) isolasi lingkungan ataupun kelas sosial, (c) pengaruh usia memberikan kontribusi yang cukup besar terhadap proses pengenalan diri.

Berdasarkan penjelasan di atas, maka dapat dipahami bahwa mahasiswa perlu memilikikonsep diri yang positif dalam menjalankan aktivitas sehari-hari, terutama ketika berada dalam situasi akademik. Dengan adanya konsep diri yang positif, mahasiswa akan dapat mencapai kesuksesan dalam kehidupan, dikarenakan ia akan berusaha mencapai tujuan hidup dan mengatasi segala permasalahan yang menghalanginya untuk mencapai tujuan tersebut.

\section{Locus of Control}

Temuan penelitianmenunjukkan bahwa rata-rata skor locus of control mahasiswa sebesar 10,44 dan standar deviasi sebesar 2.07. Berdasarkan temuan tersebut, maka dapat diketahui bahwa pada umumnya mahasiswa berada di rentang pertengahan antara internal locus of control dan external locus of control. Locus of control adalah keyakinan seseorang tentang keterkaitan antara usaha dan hasil yang diterima, sehingga mereka mampu mengontrol peristiwa dalam hidupnya. Setiap individu mempunyai kecenderungan yang berbeda-beda dalam orientasi locus of control, ada yang internal dan ada yang eksternal.

Individu yang memiliki orientasi internal locus of control merasa yakin bahwa persitiwa yang dialami dalam kehidupan mereka terutama ditentukan oleh kemampuan usaha sendiri.Mahasiswa dengan internal locus of control lebih berorientasi pada keberhasilan karena mereka menganggap perilaku mereka dapat menghasilkan efek positif dan mereka juga lebih cenderung tergolong ke dalam high-achiever (Hasan \& Khalid, 2014; Rinn, Boazman, Jackson \& Barrio, 2014).

Mahasiswa dengan external locus of controlakan menghubungkan peristiwa yang mempengaruhi hidup mereka dengan keberuntungan dan nasib yang berada di luar kendali mereka. Mereka juga merasa tidak mampu mengontrol peristiwa-peristiwa yang terjadi pada dirinya, sehingga mereka akan mudah putus asa ketika menghadapi masalah-masalah yang terjadi

Berdasarkan penjelasan di atas maka dapat dipahami bahwa mahasiswa perlu berorientasi pada internal locus of control dalam menjalankan aktivitas sehari-hari, terutama ketika berada dalam situasi akademik. Dengan adanya orientasi internal locus of control, mahasiswaakan dapat mencapai kesuksesan dalam kehidupan, dikarenakan ia akan berusaha mencapai tujuan hidup dan mengatasi segala permasalahan yang menghalanginya untuk mencapai tujuan tersebut.

Mahasiswa yang memiliki internal locus of control pada umumnya juga memiliki orientasi yang baik untuk mencapai prestasi akademik ataupun prestasi bidang lainnya. Mereka akan meyakini bahwa agar dapat meraih tujuan/keinginan maka perlu adanya usaha konkrit yang dilakukan. Mereka tidak akan melemparkan kesalahan kepada orang lain ketika ia mengalami kegagalan dalam 
mencapai sesuatu, namun mereka akan melakukan introspeksi diri mengenai penyebab kegagalan dan usaha apa yang dapat dilakukan selanjutnya agar kegagalan terulang kembali.

\section{Pengaruh Konsep Diri terhadap Motivasi Berprestasi}

Hasil analisa membuktikan bahwa terdapat pengaruh konsep diri $\left(\mathrm{X}_{1}\right)$ terhadap motivasi berprestasi $(\mathrm{Y})$. Temuan ini diperoleh berdasarkan rangkaian analisis data yang menunjukkan bahwa pengaruh konsep diri $\left(\mathrm{X}_{1}\right)$ terhadap motivasi berprestasi $(\mathrm{Y})$ sebesar7,2\%.

Temuan hasil penelitian ini sejalan dengan beberapa teori dan hasil penelitian seperti yang telah dipaparkan pada bab sebelumnya. Burns (1979) mengemukakan bahwa konsep diri yang positif dapat membantu seseorang untuk meningkatkan kepercayaan terhadap dirinya sehingga dapat memotivasi seseorang untuk dapat menjadi lebih baik lagi.Penelitian yang dilakukan Joko Prasetyo (2012) terkait pengaruh konsep diri terhadap motivasi berprestasi, ditemukan hasil bahwa terdapat pengaruh konsep diri terhadap motivasi berprestasi. Begitu juga dengan beberapa hasil penelitian lainnya (Zainalipour, Zarei \&Dayeripour ,2012; Lawrence \& Vimala, 2013; Dianto, Gistituati \& Mudjiran, 2015;Nur \& Massang, 2016).

Fink (dalam Burns, 1979) menemukan hubungan yang cukup berarti di antara konsep diri yang rendah dan pencapaian akademis yang rendah, dan hubungan ini kelihatannya lebih kuat pada anak laki-laki dibandingkan pada anak-anak perempuan.Shaw dan Alves (dalam Burns, 1979) menyimpulkan bahwa laki-laki yang prestasi akademis rendah memiliki konsep diri yang negatif dibandingkan dengan laki-laki yang berprestasi akademis tinggi.

Remaja dengan konsep diri yang positif akan mempunyai internalisasi diri yang matang. Sejumlah indikasi dari kematangan ini antara lain ditunjukkan dengan kepemilikan seperangkat kepribadian, seperti adanya jati diri, identitas diri, dan sadar diri. Dengan berbekal berbagai kepribadian ini, remaja dapat melakukan sosialisasi dengan lingkungan tanpa harus larut atau hanyut.Sebaliknya, mereka bahkan dapat memanfaatkan segenap potensi dirinya mengubah berbagai fenomena negatif menjadi positif di tengah lingkungannya.

\section{Pengaruh Locus of Control terhadap Motivasi Berprestasi}

Hasil analisa membuktikan bahwa terdapat pengaruh locus of control $\left(\mathrm{X}_{2}\right)$ terhadap motivasi berprestasi $(\mathrm{Y})$. Temuan ini diperoleh berdasarkan rangkaian analisis data yang menunjukkan bahwa pengaruhlocus of control $\left(\mathrm{X}_{2}\right)$ terhadap motivasi berprestasi $(\mathrm{Y})$ sebesar 9,5\%.

Temuan hasil penelitian ini sejalan dengan beberapa teori dan hasil penelitian seperti yang telah peneliti paparkan pada bab sebelumnya. Motivasi berprestasi ditentukan atas banyak faktor salah satunya yakni karakteristik kepribadian. Penelitian yang dilakukan Kader(2014) bahwa terdapat pengaruh locus of control terhadap motivasi berprestasi. Begitu juga penelitian yang dilakukan oleh Landine \& Stewart(1998) dengan hasil yang sama.Beberapa hasil penelitian lainnya juga membuktikan bahwa terdapat hubungan antara kedua variabel ini (Nofia, Nas \& Trisnawati, 2016; Alfitami \&Rustiana, 2018; Labhane, Nikam, Baviskar, 2015).

Berdasarkan pemaparan di atas, maka dapat dipahami bahwa locus of control memberikan pengaruh terhadap motivasi berprestasi.Oleh sebab itu, untuk meningkatkan motivasi berprestasimahasiswa dapat dilakukan dengan mengarahkan mahasiswa untuk memiliki internal locus of control. 


\section{PengaruhKonsep Diri dan Locus of Control terhadap Motivasi Berprestasi}

Hasil analisa membuktikan bahwa terdapat pengaruh konsep diri danlocus of control terhadap motivasi berprestasi. Namun demikian, tingginya konsep diri dan locus of control tidak menjadi faktor utama dalam membentukmotivasi berprestasi. Adapun sumbangan variabel $\mathrm{X}_{1}$ dan $\mathrm{X}_{2}$ terhadap Y sebesar 15,1\%.

Menurut Hamalik (2000) faktor-faktor yang mempengaruhi motivasi ialah umur, kondisi fisik, dan kekuatan inteligensi yang juga harus dipertimbangkan dalam hal ini.Selanjutnya Heider (dalam Santrock, 2003: 476) mengatakan motivasi berprestasi dipengaruhi beberapa faktor, seperti karakteristik kepribadian atau motif dari perilaku tersebut dan penyebab eksternal, yaitu faktor situasional atau faktor lingkungan seperti hadiah atau tingkat kesulitan tugas.Motivasi berprestasi merupakan unsur yang sangat penting dimiliki suatu kelompok. Mereka yang mempunyai motivasi akan lebih berhasil ketimbang kelompok yang tidak punya motivasi.

Mengingat pentingnya motivasi berprestasi, maka diharapkan dosen dapat menyelenggarakan pembelajaran yang tidak hanya berorientasi kepada perkembangan aspek kognitif, namun mampu secara merata memberikan intervensi-intervensi, khususnya yang mengarah pada meningkatnya motivasi untuk berprestasi.Mengingat kompleksnya peran pendidik, maka dibutuhkan wawasan, pengetahuan, keterampilan, nilai, dan sikap yang memadai dari pendidik itu sendiri.

\section{KESIMPULAN}

Berdasarkan temuan dan pembahasan hasil penelitian, bisa dikemukakan kesimpulan-kesimpulan sebagai berikut:

1. Konsep dirimahasiswa secara umum berada pada kategori sedang dengan rata-rata skor sebesar 70,737, artinya sebagian dari jumlah sampel yang menjadi penelitian sudah memilikikonsep diri dengan baik.

2. Rata-rata perolehan skor locus of control yakni sebesar 10.44, artinya diketahui bahwa skor ratarata perolehan locus of control cenderung berada pada rentang pertengahan antara internal locus of control dan external locus of control jika dilihat dari nilai tengah (median) sebesar 11.5.

3. Motivasi berprestasi mahasiswa secara umum berada pada kategori sedang dengan rata-rata skor sebesar 202,562, artinya sebagian dari jumlah sampel yang menjadi penelitian sudah memiliki motivasi berprestasi dengan baik.

4. Terdapat pengaruhkonsep diri terhadap motivasi berprestasimahasiswa. Artinya semakin positif konsep diri mahasiswa, maka semakin tinggi pula motivasi berprestasi.

5. Terdapat pengaruh locus of control terhadap motivasi berprestasi mahasiswa. Artinya semakin internallocus of control, maka akan semakin tinggi pula motivasi berprestasi.

6. Terdapat pengaruh konsep diri dan locus of control terhadap motivasi berprestasi mahasiswa. Artinya semakin positif konsep diri daninternallocus of control, maka akan semakin tinggi pula motivasi berprestasi.

\section{REFERENSI}

Alfitami, Dita \&Rustiana, Ade.(2018). Pengaruh Locus of Control Internal, Locus of Control Eksternal, Manajemen Waktu, dan Kreativitas Mengajar Terhadap Motivasi Berprestasi.Economic Education Analysis Journal, 6 (3). 
Arvyaty., Maonde, Faad \& Noho, Naimin. (2016). Pengaruh Motivasi Berprestasi Terhadap Prestasi Belajar Matematika Siswa SMA Negeri dan SMA Swasta Di Kota Kendari.Jurnal Pendidikan Matematika, 7 (1): 26-42.

Awan, Riffat-Un-Nisa., Noureen, Ghazala., Naz, Ms. Anjum. (2011). A Study of Relationship between Achievement Motivation, Self Concept and Achievement in English and Mathematics at Secondary Level.International Education Studies, 4 (3): 72-79.

Black, H. K. (1999). A sense of the sacred: Altering or enhancing the self-portrait in older age?.Narrative Inquiry, 9, 327-345.

Burns. (1979). Konsep Diri: Teori, Pengukuran, Perkembangan dan Perilaku. Terjemahan oleh Eddy. 1993. Jakarta: Arcan.

Dianto, Mori., Gistituati, Nurhizrah \& Mudjiran. (2015). Kontribusi Dukungan Sosial dan Konsep Diri Terhadap Motivasi Berprestasi Siswa di SMP Negeri Kecamatan Batang Kapas Pesisir Selatan.Konselor, 4 (1): 19-25.

Diniaty, Amirah. (2001). Keikutsertaan Siswa Pada Lembaga Bimbingan Belajar Dalam Kaitannya dengan Motivasi Berprestasi, Kemampuan dan Maslah Belajar Serta Peranan Guru Pembimbing Di SMUN 1 Padang. Tesis tidak diterbitkan. Padang: Program Pascasarjana Universitas Negeri Padang.

Donal. (2014). Kontribusi Konsep Diri dan Motivasi Berprestasi Terhadap Arah Perencanaan Karier Siswa (Studi Pada SMAN 2 Kampar Kiri). Tesis tidak diterbitkan, Padang: PPs FIP UNP.

Eccles, 1.S., O'Neill, S.A., \& Wigfield, A. (2005).Ability Self-Perceptions and Subjective Task Values in Adolescents and Children. K.A. \& Lippman, L.H. (Eds.), What do children need to flourish: Conceptualizing and measuring indicators of positive development. New York: Springer Science \& Business Media.

Emmanuel,Affum-Osei., Adom,Eric Asante \&Josephine,Barnie. (2014). Achievement Motivation, Academic Self-Concept and Academic Achievement Among High School Students.European Journal of Research and Reflection in Educational Sciences, Vol. 2 No. 2: 24-37.

Fink, M.B. (1962). Self Concept as it Relates to Academic Underachievement. California Journal od Educational Research, 13: 57-62.

Hasan, Syeda Salma \& Khalid, Ruhi. (2014). Academic Locus of Control of High and Low Achieving Students.Journal of Research and Reflections in Education, 8 (1): 22 -33.

Harjanto, Eka.(2015). Pengaruh Motivasi Berprestasi dan Kompetensi Pedagogik terhadap Kinerja Mengajar Guru. Jurnal manajemen Pendidikan, Volume 24, Nomor 5, 456-466.

Harumi, Azalia \&Kumoro, Joko. (2016). Pengarub Motivasi Berprestasi dan Minat Belajar Terbadap Prestasi Belajar Mata Pelajaran Korespondensi. Makalah disajikan pada Seminar Nasional Penguatan Hubungan antara Pengembangan Keterampilan, Pendidikan, dan Ketenagakerjaan Generasi Muda, Universitas Sebelas Maret. 
Herrero, Diane M.(2014). The relationship Among Achievement Motivation, Hope, and Resilience and Their Effects on Academic Achievement Among Firstyear College Students Enrolled in A Hispanic-Serving Institution.Disertasi tidak diterbitkan, Texas A\&M University-Corpus Christi.

Jeffrey \& Zein, Ade.(2017). The Effects of Achievement Motivation, Learning Discipline and Learning Facilities on Student Learning Outcomes. International Journal of Development Research, 7 (9): 15471-15478.

Kader, Ahmad A.(2014). Locus of Control, Student Motivation, and Achievement in Principles of Microeconomics. American International Journal of Contemporary Research, Vol. 4, No. 9.

Karim, M. (2016). Analisa Mengenai Motivasi Berprestasi Mahasiswa Fakultas Tarbiyah dan Ilmu Keguruan Insitut Agama Islam Negeri (IAIN) Kerinci. Jurnal Tarbawi, Vol. 12, No. 2: 34 46

Kaur, Sukhvir. (2013). Academic Achievement in Relation to Achievement Motivation of High School Students.International Journal of Science and Research (IJSR), Vo. 2, Issue. 12: 409-411

Kumari, V. R. Santha \& Chamundeswari, S. (2015). Achievement Motivation, Study Habits and Academic Achievement of Students at the Secondary Level.International Journal of Emerging Research in Management \&Technology, Volume. 4, Issue. 10: 7-13

Kutanis, Rana Özen., Mesci, Muammer \& Övdür, Zeynep. (2011). The Effects of Locus of Control on Learning Performance: A Case of an Academic Organization. Journal of Economic and Social Studies, Vol. 1, No. 2: 116.

Labhane, C. P. , Nikam, H. R., Baviskar, Pravin A. (2015). A Study of Locus of Control and Achievement Motivation among students of Jalgaon Dist.The International Journal of Indian Psychology, 3 (7): 104-111.

Landine, Jeffrey \& Stewart, John.(1998). Relationship Between Metacognition, Motivation, Locus of Control, Self-Efficacy, and Academic Achievement. Canadian Journal of Counselling / Revue Canadienne De Counseling, Vol. 32, No. 3.

Lawrence \& Vimala.(2013). Self-Concept and Achievement Motivation of High School Students.Conflux Journal of Education, 1 (1): 141-205.

Levenson, H. (1981). Differentiating among Internality, Powerful Others, and Chance. Lefcourt, $\mathrm{H}$ (Ed.), Research with the Locus of Control Construct, (Online), Vol. 1, (http://www.hannalevenson.com/publications.html, diakses 27 Februari 2018).

Makmun, Abin Syamsuddin. (2001). Psikologi Kependidikan. Bandung: PT Remaja Rosdakarya.

Manafi, Donya., Mohammadi, Sayed Hamid Movvahed., Hejazi, Sayed Yousef. (2015). Factor Analysis of Studentís Achievement Motivation Variables (Case Study: Agricultural Ms.C Student in Tehran University). International Journal of Advanced Biological and Biomedical Research, 3 (2), 134-138.

McClelland, D. C. (2010).The Achieving Sosiety. Princeton, New Jersi: Martino Publishing. 
Mnyandu, Pamela Tinky. (2001). The relations between self-determination, achievement motivation and academic achievement. Tesis tidak diterbitkan. South Africa: University of South Africa.

Munir, Saima \& Sajid, Mehsoon.(2010). Examining Locus of Control (LOC) as a Determinant of a Organizational Commitment among University Professors in Pakistan. Journal of Business Studies Quarterly, (Online), Vol. 1, No. 3, (jbsq.org/wpcontent/uploads/2010/10/JBSQ 4F.pdf, diakses 27 Februari 2018).

Nasreen, Abida \& Naz, Anjum.(2013). A Study of Factors Effecting Academic Achievement of Prospective Teachers.Journal of Social Science for Policy Implications, 1(1): 23-31.

Neil, James. (2006). What is Locus of Control. (Online), (http://wilderdom.com/ jamesnerill.html, diakses 27 Februari 2018).

Nofia, Imelda., Nas, Syakdanur \& Trisnawati, Feny. (2016). Effect of Internal Locus of Control of Achievement Motivation in Economic Subject Class XI SMAN 2 Mandau.Jurnal Online Mahasiswa, 3 (1): 1-12.

Nur. M. \& Risnawita, Rini S. (2012). Teori-teori Psikologi. Yogyakarta: Ar-ruzz Media.

Nur, Andi Saparuddin \& Massang, Berdinata. (2016). Pengaruh Pola Asuh Orang Tua, Konsep Diri, dan Motivasi Berprestasi terhadap Prestasi Belajar Matematika Siswa Kelas IX SMP Negeri di kota Merauke. Suska Journal of Mathematics Education, 2 (2): 89 - 96.

Oemar Hamalik. (2000). Psikologi Belajar dan Mengajar. Bandung: Sinar Baru Algensindo.

Oktaviani, Chiktia Irma. (2014). Konsep Diri Remaja dari Keluarga Broken Home. Tesis tidak diterbitkan. UIN Maulana Malik Ibrahim.

Pardede, Yudit Oktaria Kristiani. (2008). Konsep Diri Anak Jalanan Usia Remaja. Jurnal Psikologi. Volume 1, No. 2: 146-151.

Prabadewi, Komang Diah Laxmy \& Widiasavitri, Putu Nugrahaeni. (2014). Hubungan Konsep Diri Akademik dengan Motivasi Berprestasi pada Remaja Awal yang Tinggal di Panti Asuhan di Denpasar.Jurnal Psikologi Udayana, 1 (2): 261-270.

Prasetyo, Joko.(2012). Pengaruh Konsep Diri dan Lingkungan Keluarga Terhadap Motivasi Berprestasi Siswa Program Studi Teknik Kendaraan Ringan di SMK Muhammadiyah Gamping Tahun Ajaran 2010/2011. Skripsi tidak diterbitkan. Yogyakarta: Program Studi Pendidikan Teknik Otomotif Fakultas Teknik Universitas Negeri Yogyakarta.

Pudjijogyanti, Clara R. (1988). Konsep Diri dalam Pendidikan. Jakarta: Arcan.

Purwanti, Yanti Dewi., Koentjoro\& Purnamaningsih, Esti Hayu. (2000). Konsep Diri Perempuan Marginal. Jurnal Psikologi. No. 1: 48-59.

Puspasari,Amaryllia. (2007). Mengukur Konsep Diri Anak. Jakarta: Elex Media Komputindo.

Raven, Bertram Herbert.(2000). Social Psychology. United States: Wiley And Sons, Inc. 
Rinn, Anne N., Boazman, Janette., Jackson, Ann \& Barrio, Brenda. (2014). Locus of control, academic self-concept, and academic dishonesty among high ability college students.Journal of the Scholarship of Teaching and Learning, 14 (4): 88 - 114.

Rotter, J.B. (1966). Generalized Expectancies for Internal Versus External Control of Reinforcement. American Psychological Association, vol. 80, No. 1: 1.

- (1989). Internal Versus External Control of Reinforcement: A Case History of a Variable. American Psychological Association, (Online), Vol. 45, No. 4,(mres.gmu.edu/readings/PSYC557/Rotter1990.pdf, diakses 27 Februari 2018).

Santrock, John. W. Perkembangan Remaja. Terjemahan oleh Shinto B. Adelar dan Sherly Saragih. (2003). Jakarta: Erlangga.

Schultz, Charles B. \& Pomerantz, Michael. (1976). Achievement motivation, locus of control, and academic achievement behaviour.Journal of Personality, Vol. 14, Issue. 1: 38-51

Sudarma, Ketut \& Nugraheni, Fitria.(2006). Pengaruh Motivasi Berprestasi dan Strategi Belajar Efektif Terhadap Prestasi Belajar Akuntansi.Dinamika Pendidikan, 1 (1): 28-43.

Sukada, I K., Sadia, W., Yudana, M.(2013). Kontribusi Minat Belajar, Motivasi Berprestasi dan Kecerdasan Logis Matematika Terhadap Hasil Belajar Matematika Siswa SMA Negeri 1 Kintamani. e-Journal Program Pascasarjana Universitas Pendidikan Ganesha Program Studi Administrasi Pendidikan, Volume 4.

Sutoyo,Anwar. (2009). Pemahaman Individu, 'Observasi, Checklist, Kuesioner \& Sosiometri", Semarang: CV. Widya Karya.

Toding,Wastie R. B., David,Lydia.,Pali, Cicilia. (2015). Hubungan Dukungan Sosial dengan Motivasi Berprestasi pada Mahasiswa Angkatan 2013 Fakultas Kedokteran Universitas Sam Ratulangi.Jurnal e-Biomedik (eBm), Volume. 3, Nomor. 1.

Zainalipour, Hossein, Zarei, Eghbal \& Dayeripour, Fatemeh.(2012). Study of Individual Factors Influencing on Academic Achievement Motivation in High-School Female Students. Journal of Educational and Management Studies, 2 (2): 43-47. 